\title{
A study on feminist scholarship and human rights activism against practices of gendered- based violence: focused on Korean comfort women movement
}

\author{
Binur Balaubaeva ${ }^{1, *}$, Sania Nuralieva $^{l}$ Syrym Parpiyev ${ }^{1}$ \\ ${ }^{1}$ Al-Farabi KazNU, pr. al Farabi, 71, 050040 Almaty, Republic of Kazakhstan
}

\begin{abstract}
This article focused on the Korean comfort women issue(Chongshindae issue).The Chongshindae issue is not just a question, which was silent for about 50 years. It has an important influence on contemporary times in Korean and other Asian societies. Moreover, it can prevent future problems related to social class, gender issues, violations against women and the impact of patriarchal organizations. This article argues, first, the issue of the comfort women system during the war between Japan and South Korea evolved into a universal dispute in the contemporary world. Moreover, not only Korean feminists, but also feminist scholars and human rights activists from different countries were involved. In otherwise, it is important to note that the gender hierarchy and patriarchal society in both countries of Japan and Korea limited the opportunities of feminists and human rights activists over the comfort women issue. The Controversial AWF seemed like a tool of Japan to avoid their legal responsibility and official apology. Nevertheless, the Chongshindae movement had achieved remarkable success regarding the comfort women issue, despite the controversies between the two countries, especially in establishing the historical monument. Moreover, a feminist national context helped to raise the issue of comfort women as a political issue, and made it symbolic.
\end{abstract}

\section{Introduction}

On 6 February 1996, the United Nations declared its final condemnation of Japan, which forced approximately 200,000 young women into sexual service during the Asia-Pacific War between 1937-1945[1]. According to a report by Radhika Coomaraswamy, who was a special researcher of violence against women, Japan had to apologize in writing, admit to its legal responsibility, find and punish those people who were responsible, compensate the victims and change Japanese history books for students [1]. Although there many examples of violations against women in armed conflicts and during war time, the purpose of this paper is to focus on the Korean "comfort women" issue and analyze the evolution of the Korean

\footnotetext{
${ }^{*}$ Corresponding author: binur77@mail.ru
} 
comfort women's movement with contributions from feminist scholars and human rights activists from different organizations. This article will focus on the Korean comfort women issue because they make up $80 \%$ of the 200,000 and most of them were from an impoverished working-class background [2]. However, it is important to draw attention to the fact that women from Japan and occupied Taiwan, Burma, Thailand and the Philippines were also victims of the comfort women system. This problem is also still contested and complicated by feminists; therefore, a deeper understanding is required.

In order to address this problem, the article will be divided into several parts. First, this article will give the background history of the "comfort women" issue, and second, explain its possible causes. Third, this article will discuss the Korean comfort movement $\left(\right.$ Chongshindae $^{2}$ ) which was created in 1991 and the influence of feminist scholars and human rights activists. Fourthly, we will discuss the Japanese response with regard to the Korean comfort women issue and controversial Asian Women's Fund. Additionally, the response of the international community will be provided throughout the paper. Then, the current situation between Japan and South Korea will be analysed before being concluded.

\section{Historical background of Korean Comfort Women}

In order to better understand this transnational dispute between Japan and South Korea, a historical background will be provided. During 1932-1945 Japan was involved in the AsiaPacific War with many Asian countries and the United States. As a result, the Japanese government mobilized around 200,000 women into military brothels in order to comfort their soldiers during the war [3]. Japanese troops in Shanghai built the first "comfort stations" in the beginning of 1932 [2]. The reason for establishing the comfort stations was to prevent the random rape of women in occupied countries [4]. It is important to note that the military sexual service system was formed between 1937-1938. At that time, Japan commenced the war against China and occupied Nanking [3]. Consequently, during the 1940s, the Japanese government started to establish the military comfort stations in other Asian countries too, such as, Thailand, Burma, Indonesia and the Philippines.

It is still unknown how many women were involved in military brothels during the war because the Japanese government destroyed all records and documents about comfort women. An exception is the Dutch comfort women issue that was documented in their government report [5]. However, there remained few documents, which revealed information about the ratio of comfort women to Japanese soldier s[3].

It is important to consider that rape was used as a weapon of war, such as in Bosnia and Kosovo [6]. According to Mackinnon, "rape in war has so often been treated as extracurricular, as just something men do, as a product rather than a policy of war."'[6] Compared to Bosnia and Kosovo, and the Serbian war of genocide, Japan was private. The use of condoms was important in Japanese comfort stations to prevent pregnancy and venereal diseases [4]. However, beyond this system, many details are still unrevealed such as, the system of recruitment, how it was paid and the conditions of work. Moreover, the information could differ depending on the period and location of the comfort stations [7].

According to Min, Korean men were forced to serve in the Japanese military, while the women were forced into sexual slavery. Although other Asian women were victims of the Japanese government, the vast majority of comfort women were from Korea because it was a colonial country under Japanese imperialism. Also, the Japanese government mobilized women from Taiwan, but compared to the Korean victims they were fewer because of their small population [3]. Regarding that, many Japanese scholars agreed with Korean scholars

2 The term of 'Chongshindae' literally means "a corps which voluntarily sacrifices bodies for the Japanese State(Emperor)". 
in that "the victimization of many Korean comfort women under Japanese military sexual slavery was partly a by-product of Japan's colonization of Korea" [3]. Yoshimi argued that the Japanese military did not mobilize Japanese virgins to avoid public mistrust of the military [4]. Young Korean women were abducted and were victims of false promises of employment [3]. Forcing Korean women was more effective than forcing women from other Asian countries because Korea was governed totally by the Japanese government. Thus, colonial power crossed over gender and social class, where most of the young women were from poor families.

\section{Possible causes of the Korean comfort women issue}

Here are some assumptions for why the Japanese military mobilized more women from Korea. The first reason might be colonial prejudice against Koreans. Whether men or women, they were considered as tools for military purposes; therefore, women were used inhumanly [3]. Yoshimi, a Japanese historian, offered another possible reason about the Korean comfort women. He stated the assumption that the Japanese chose Korean women for the comfort stations because the Japanese thought they did not violate international law. In 1921, the Japanese government ratified another convention, the International convention for the Suppression of the Traffic in Women and Children [4]. Later, the convention included Article 11, where colonial countries would not be able to apply to this convention [3]. Thus, according to this assumption, Japan thought that it did not violate international law.

Members of the Korean Council and Research Association provided an interview with about 76 survivors' testimonies [3]. According to the victims' stories, the Japanese government provided horrible conditions and experiences. Comfort women were forced to have intercourse with soldiers more than 30 times per day [3].Furthermore, they were tortured, beaten, and even burned. Some women died because of venereal diseases in military comfort stations.

It is important to point out the patriarchal and gender hierarchy system in South Korea with regard to comfort women survivors. Most of the victims were from an impoverished social class and could not protect themselves under the law [1]. In addition, it was of great shame to them to admit that they were raped for a few years [8], perhaps because of the strict society they were in. Even though some victims of the comfort stations returned home alive, most of them could not live with their families because of mental and physical damage. Some of them was married but then quickly divorced because of their infertility [9]. The next chapter discusses the comfort women movement and how they broke their silence about Japanese aggression.

\section{Evolvement from a bilateral issue into an international human rights issue}

The experiences of the Korean women were a result of the intersection of colonial power, patriarchal society, gender hierarchy and social class. Therefore, this issue required more attention not only at regional, but also at the international level. During the 1970s, South Korea's first women's movement created a campaign against international sex tourism [1]. The movement's purpose was against Japanese male visitors, and developed into a postcolonial dispute between Japan and Korea[1]. When feminist human rights activists raised the question of Chongshindae (the comfort women issue), the Korean government ignored that situation because of a lack of evidence [1]. As a result, South Korea and Japan have never raised the question of comfort women since 1965, when the bilateral agreement 
between countries was established, which declared that the compensation to Korea from Japan was completely and finally paid [10].

By the end of the 1980s, Korean feminists started to pay attention to the comfort women issue more seriously [3]. In 1988, the Korean Church Women United organized the International Conference on Women and Tourism [2]. Yu Chung-Ok from Ewha Woman's university introduced her presentation about the Chongshindae issue for the first time. The research helped to analyse the relationship between comfort women in Japanese colonial times and kisaeng sex tourism in South Korea. In 1989, a participant of a women's organization sent a letter to the Korean government demanding that they address the Chongshindae issue, with an official apology from Japan [1].Thus, in 1990, Korean feminists from about 36 organizations created the Korean Council Drafted for Sexual Slavery by Japan against the Japanese government [3]. In addition, a Korean women's movement developed simultaneously with the Minjung movement. Minjung feminism derived from the idea of the liberation of women who were super-exploited and overused in the industry field [8]. The Minjung feminist movement helped comfort women survivors with shelter and support, and speak out after 50 years of silence. They worked together with feminist professors from the Korean Council, Korean church and community groups, as well as with the Korean women's movement, Japanese feminists and human rights activists. Consequently, they organized the Women's Hot Line in Seoul [8].

According to Soh, the remarkable success of Korean feminist activists over comfort women was because of two factors: domestic and international. In terms of domestic factors, the democratization process during 1987 and UN membership in 1991 was important for Korean women. "The political opportunity structure" was a crucial point for the feminist human rights activists to raise the issue of comfort women publicly as a postcolonial dispute with Japan [8]. Consequently, in 1991, the Chongshindae movement witnessed a historic moment. Kim Hak-sun publicly stated that she was a victim of the comfort women system during the war [11]. Another crucial moment happened when Japanese historian Yoshimi declared the official documents about comfort women. This document finally proved that the Japanese military was part of the military comfort women system[4]. The Korean Council helped about 200 comfort women tell their story, which gave rise to the creation of the comfort women's movement for redress [3]. According to Min, feminist organizations from Korea tried to organize a coalition with women from Japan, other Asian countries and international feminist human rights activists to force Japan to admit its legal responsibility to comfort women. Consequently, Chongshindae movement for redress increased the investigation over the comfort women issue, which led to the creation of books, articles and news stories, concentrating on the issue, in Japan and other Asian countries [3]

After the public testimony of Kim Hak-sun in 1991, the Association of Pacific War victims and Bereaved Families sponsored feminist Korean activists to file a lawsuit against the Japanese government[1]. They demanded an official apology and compensation of about $\$ 2.29$ million [1]. It is important to note the role of Korean and Japanese feminist activists in raising the public consciousness on the military comfort women issue, including the leaders of the Chongdaehyop, Yun Chung-ok and Lee Hyo-chae [1].

The Japanese government did not admit their involvement in the military comfort women issue until Japanese historian, Yoshimi, publicized the official documents that confirmed their involvement in the comfort system [1]. In 1992, the NGO, Korean Council for Women Drafted for Military Sexual Slavery by Japan, made a petition for the United Nations Commission on Human Rights (UNCHR) to conduct research about comfort women. In that year, the Korean women's movement was supported by the Korean Council and presented the comfort women issue in UNCHR meetings [1]. Moreover, they started to organize solidarity through the contribution of organizations from other afflicted countries. The purpose of the Korean Council was to build solidarity and recognise the victims of the 
comfort women system not only from South Korea, but also from China, North Korea, Thailand, Burma and the Netherlands[7]. The dispute between South Korea and Japan enabled the rethinking of the issue of sexual violence against women in conflict zones at the international level. The Korean Chongshindae movement indicated the important role of feminists' political activities in the politicization of the comfort women issue[1].

\section{Japanese discourse and the controversial Asian Women's Fund}

When Yoshimi revealed the documents confirming the comfort women system, contemporary Japan was divided into proponents and opponents. After the UNCHR declaration, Japan did not admit their involvement until 1993, and rejected to pay compensation for survivors[1]. It is important to consider that both governments are ruled by mostly male elite, and have seen this problem as an economic compensation issue, rather than as women's human rights violations. Some Japanese feminist activists were critical of the Korean comfort women movement because Japanese women also suffered during the war[3]. Even surviving Japanese soldiers did not support the movement's requirement by claiming that everyone was a victim of the war[1].

According to Yun Chung-ok, in December 1992, South Korean national fund-raising raised about 200 million won, about \$250,000, for comfort women survivors (Soh, 1996). However, in 1993, the new president of South Korea declared the government position with regard to this issue. According to the new administration, the government did not require material compensation, but would ask the Japanese government to conduct thorough research about military stations, in addition to a formal apology. The new presidential position positively influenced the bilateral relationship, and in response, Japan recognised their involvement in the recruitment of women into military comfort stations. Moreover, Japan admitted that the government violated international law by persecuting Korean woman[1]. In 1994, the International Commission of Jurists suggested Japan compensate each surviving woman with about $\$ 40,000$. Then, the Japanese government declared that payment would be made through non-governmental funds, and that the government would provide the medical and welfare expenses. Feminist activists refused this compensation from non-governmental funds in 1995 in the Asian Women's Solidarity Forum's third conference, and demanded compensation only from the government[1]

According to Kumagai, in 1996, the Japanese government approved of history text books, which reflected the backlash regarding comfort women, in which some of the information might have been deleted[12]. This situation again created tensions in the bilateral relationship of Japan and South Korea. The textbooks seemed to ignore the real facts about comfort women, and expressed disrespect towards South Korea and other Asian countries. The Japanese government delegation actively supported the International Symposium on Violence Against Women in War and Armed Conflict, while at the United Nations World Conference on Women in Beijing they kept silent about the "comfort women" issue[1].

In response to comfort women activists, the Japanese government decided to create the Asian Women's Fund[7]. The Asian Women's Fund (AWF) was established as a nongovernmental organization "with the aim of expressing a sense of national atonement from the Japanese people to the former 'comfort women', and to work to address contemporary issues regarding the honor and dignity of women"[7]. Feminist activists of Japan and other Asian countries denounced calls that this fund was created to evade the legal responsibility of Japan over the comfort women issue. The AWF caused many controversies among the feminist human rights activists and the Japanese government since it was established. After establishing the AWF, Japanese companies and the business sector did not want to donate to the organization [7]. They complained that slavery and brutal relations against victims were a common practice among colonizer countries, and claimed that Japan is not the only country 
responsible for war crimes. Consequently, the fund raised money from ordinary people to about 448 million yen (\$5 million USD) during 1995-2000. The Japanese government granted over several hundred million dollars to support the budget of the fund [7].

Interestingly, the response to the Japanese government and the AWF was very divergent. However, Korean and Taiwanese leaders of comfort women movements have hard line dogmatic positions, in contrast to Indonesia and the Netherlands. Korean comfort women movement leaders urged survivors that Japan wanted to avoid legal responsibility so they would not receive compensation from the fund. However, it is important to note that compared to survivors from the Philippines and other Asian countries, Korean survivors were paid every month by the government; therefore, they may have been in a strong position.

Nevertheless, in 1997, about seven Korean survivors accepted the autonomy money from the AWF, which not only insulted the women's movement, but also divided survivors into proponents and opponents of the apology [7]. The Korean Council organized the fund-raising campaign and about 140 survivors received payment (except for seven survivors receiving AWF payments. Consequently, the 140 survivors promised and signed not to take support from the AWF (ibid.). For the Korean Council, it seemed like a victory against the fund. They requested use of the fund money to teach students about the comfort women issue and change the project [7]. However, some Japanese scholars, such as Wada, expressed their disagreement with decision of the Korean Council (Asahi Shimbun, 1998 cited in Soh, 2003). Wada stated that halmonis (Korean grandmothers) have the right to receive the autonomy fund as an apology [7]. In addition, he declared that Japanese people wished to embrace the seven survivors who accepted the support from Japan [7]. Moreover, the fund is considered to be a symbolic gesture of the Japanese apology. However, because of disputes between supporters and opponents, many Korean survivors refused the compensation. An interesting fact is that, in contrast to the South Korean situation, only one male lawyer from Taiwan was willing to help survivors accept money, if they wished [7]. This might be because of cultural prejudice over gender issues. However, on the contrary, the political climate around women for comfort worsened after AWF was created, and the problems became even more noticeable. This is partly due to the negative reaction that followed the creation of AWF and its attempts to solve the problem [13]. Consequently, the AWF finished its function in 2007 [12]. The discussion about the current situation of the comfort women issue will now be analysed.

\section{Current controversies and memorializing the comfort women}

The South Korean government, with feminist activists and human right protectors, continued to require the Japanese government to solve this problem definitively. As a protest, on December 14 2011, to commemorate the 1000th weekly protest requiring Japan's apology and compensation, the non-governmental organization group, the Korean Council for the Women drafted for Military Sexual Slavery by Japan, (Hankuk Jungshindae Munjae Daechaek Hyopuihoe) established the Comfort Women Peace Monument [10]. The monument was opened in front of the Japanese Embassy and caused diplomatic tensions between Japan and South Korea [10]. According to the Japanese government, the location of the girl statue near the embassy violates Clause 22, Article 2, of the Vienna Convention, referring to respecting the dignity of foreign diplomatic representatives [10]. However, the Japanese government did not achieve success because the monument did not express an aggressive message towards the Japanese embassy, and it is called the "Comfort Women Peace Monument" [10]. The confrontation between Japan and South Korea was covered in other areas too, such as, the US and Europe [12]. Nevertheless, South Korea and Japan achieved an agreement in 2015 (Tisdall, 2015) after a long dispute. Previously, in 2007, Prime Minister Abe denied the facts about the comfort women system, made him the most 
unpopular person in South Korea, leading to him being refused a meeting with the South Korean president twice [14]. Abe stated that he believes that the war in Japan and the behavior of the Japanese military were righteous, and therefore he began efforts to restore his grandfather's honor by fighting back against a new research and subsequent campaigns. Some of the main arguments of these pro-Abe groups are that the Nanjing massacre and facts, which connected with «Korean comfort station» was fabricated, instead, comfort women were ordinary prostitutes and not victims of war crimes for comfort, and that Japan did not act aggressively [15].

The Japanese position might be clearer, if they sent an official apology letter. Consequently, Abe expressed his apology towards comfort women and offered to establish a new fund with 1 billion yen directly from the government [15]. However, according to Hiroka Shoji, East Asian researcher at Amnesty International, this agreement is more a political agreement, rather than an achievement of justice [15]. Moreover, Japan avoids changing the history books over comfort women, which underplays the heavy war crime of the Japanese government [17]. The diplomatic tension over the comfort women monument still has not been resolved, and continues to be a major problem between Japan and South Korea. However, it could be resolved if Japan fully and officially apologizes and sends government letters to the "halmonis" Nevertheless, it is important to recognise the work of feminist scholars and human rights activists, who achieved huge success in making the issue international and political discourse, despite the patriarchal and gender hierarchical societies in which the issue was based.

\section{Conclusion}

The Chongshindae issue is not just a question, which was silent for about 50 years. It has an important influence on contemporary times in Korean and other Asian societies. Moreover, it can prevent future problems related to social class, gender issues, violations against women and the impact of patriarchal organizations. To summarize the main argument of this paper, first, the issue of the comfort women system during the war between Japan and South Korea evolved into a universal dispute in the contemporary world. Moreover, not only Korean feminists, but also feminist scholars and human rights activists from different countries were involved. At the end of World War II, the emergence of the Human Rights Declaration (1948) and media attention to the war crimes against women in different conflict zones, gave opportunities to rethink the military comfort women and hear their voices [17].

In otherwise, it is important to note that the gender hierarchy and patriarchal society in both countries of Japan and Korea limited the opportunities of feminists and human rights activists over the comfort women issue. The Controversial AWF seemed like a tool of Japan to avoid their legal responsibility and official apology.

Nevertheless, the Chongshindae movement had achieved remarkable success regarding the comfort women issue, despite the controversies between the two countries, especially in establishing the historical monument. Survivors not only in Korea, but also from other Asian countries could tell their truth and be supported. Moreover, a feminist national context helped to raise the issue of comfort women as a political issue, and made it symbolic.

Widespreading transnational feminism and the creation of new advocacy networks is noteworthy. On the one hand, the collective activities of the survivors pursued various international legal channels in order to gain more voice in this matter. International human rights groups engaged in advocacy and the Korean Council organized numerous campaigns and tribunals to expand the international dimension of 'comfort women'. 


\section{References}

1. C. Soh, (1996). The Korean "Comfort Women": Movement for Redress. As. Sur., 36,12, pp.1226-1240, (1996)

2. Y. A. Chai, Asian-Pacific-Feminist Coalition Politics: The Chongshindae/Jugunianfu. Kor. Stud., 17, pp.67-91 (1993)

3. P. Min, Korean "Comfort Women". Gender \& Society, 17(6), pp.938-957 (2003)

4. Y. Yoshimi, Comfort women. (1st ed., New York: Columbia University Press. 2002)

5. T. Tanaka, Japan's comfort women: sexual slavery and prostitution during World War II and the US occupation. (1st ed., London: Routledge, 2002)

6. C. MacKinnon, Are women human? and other international dialogues. (1st ed., Cambridge: The Belknap Press of Harvard University Press, 2006)

7. C. Soh, Japan's National/ Asian Women's Movement Fund for "Comfort Women". Pac. Aff., 76, 2, pp.209-233, (2003)

8. M. Louie, Minjung feminism Korean Women's Movement for Gender and Class Liberation. Wom. Stud. Int. For., 18,4, pp.417-430, (1995)

9. C. Soh, In/fertility among Korea's "comfort women" survivors: A comparative perspective. Wom. Stud. Int.For., 29,1, pp.67-80, (2006)

10. M. Kim, Memorializing Comfort Women: Memory and Human Rights in Korea-Japan Relations. As. Pol. \& Pol., 6(1), pp.83-96 (2014)

11. K. Kimura, Discourses about Comfort Women in Japan, South Korea, and International Society. Int. Rel. and Dip., 3,12 (2015)

12. N. Kumagai,The Background to the Japan-Republic of Korea Agreement: Compromises Concerning the Understanding of the Comfort Women Issue. As.-Pac. Rev., 23, pp.6599, (2016)

13. H. Wada, Ianfu Mondaino Kaiketsuno Tameni: Ajia Joseikikin no Keike[For Resolution of the Comfort Women Issue: Learning from the AWF experiences], (Tokio: Heibonsha. 2015)

14. S. Tisdall, Korean comfort women agreement is a triumph for Japan and the US, The Guardian, [online] 28 Dec. Available at: $<$ https://www.theguardian.com/world/2015/dec/28/korean-comfort-women-agreementtriumph-japan-united-states-second-world-war>, (2015) [Accessed 10 Feb 2020]

15. J. McCurry, Japan and South Korea agree to settle wartime sex slaves row, The Guardian, [online] 28 Dec. Available at: <https://www.theguardian.com/world/2015/dec/28/japanto-say-sorry-to-south-korea-in-deal-to-end-dispute-over-wartime-sex-slaves >,(2015) [Accessed 10 Feb 2020]

16. S. Han, J. C. Griffiths, Why this statue of a young girl caused a diplomatic incident, CNN, [online] 10 Feb. Available at: <http://edition.cnn.com/2017/02/05/asia/south-koreacomfort-women-statue/> [Accessed 9 Feb 2020]

17. H. Hayashi, Disputes in Japan over the Japanese Military «Comfort Women» System and Its Perception in History. The An. of the Am.Acad.,617, pp. 123-132, (2008) 